\title{
A rare cause of postnasal drip and nasal obstruction: Isolated sphenochoanal polyp
}

\author{
Geniz akıntısı ve burun ttkanıklığının nadir bir sebebi: izole sfenokoanal polip
}

Önder Akdeniz, Fevzi Solmaz, Mehmet Haksever, Davut Akduman, Ercan Gündoğdu

\begin{abstract}
Choanal polyps are benign solitary masses, arising within the sinus and protruding into nasal cavity. The nomenclature is made according to the sinus that it is originated from. Sphenochoanal polyp (SCP) is quite rare, originates from sphenoid sinus, passes through the sphenoethmoid recess and elongates to nasopharynx and oropharynx. It may be confused with antrochoanal polyps on anterior rhinoscopy. Radiological examination with computerized tomography and nasal endoscopy are important in the differentiation of these two types of choanal polyps. Endoscopic approach for the complete removal of the SCP including its mucosa of the site of origin is extremely safe, which has minimal risk of recurrence. Herein we report a 30 years-old male patient with SCP, which was removed via endoscopic transnasal surgery. He had no recurrence at postoperative 9 months of follow-up. . J Clin Exp Invest 2015; 6 (2): 183-185
\end{abstract}

Key words: Nasal obstruction, nasal polyp, paranasal sinus disease, nasal surgical procedure

\section{INTRODUCTION}

Choanal polyps are benign solitary masses, arising within the sinus, protruding into nasal cavity and most commonly originate from the maxillary sinus antrum [1]. The classification and nomenclature is made according to the sinus that it is originated from, as antrochoanal, ethmochoanal and sphenochoanal polyps (SCP) respectively. SCP is quite rare, originates from sphenoid sinus, passes through the sphenoethmoid recess and elongates to nasopharynx and oropharynx. It is seen as a form of cystic polypoid mass. It may be confused with antrochoanal polyps because of their similarity in appearance and symptoms. In differential diagnosis, transnasal endoscopy, computed tomography (CT) and magnetic resonance imaging (MRI) is mainly used in the diagnosis of sinonasal masses [2].

\section{ÖZET}

Koanal polipler, sinüs mukozasından kaynaklanıp nazal boşluğa doğru çıkan, iyi huylu soliter lezyonlardır. Adlandırma kaynaklandığı sinüse göre yapılır. Sfenokoanal polip (SKP) oldukça nadir görülür ve sfenoid sinüsten kaynaklanıp sfenoetmoid resesten geçerek nazofarenks ve orofarenkse uzanır. Anterior rinoskopide antrokoanal poliplerle karıştırılabilir. Bilgisayarlı tomografi ve nazal endoskopi bu iki koanal polip tipinin ayrımında önemlidir. Endoskopik yaklaşımla SKP'in kaynakladığı mukoza ile birlikte tamamen çıkarılması oldukça güvenli olup nüks açısından minimal riske sahiptir. Bu çalışmada, sfenokanal polibi bulunan ve bu kitlesi endoskopik transnazal cerrahi ile çıkarılan, 30 yaşında bir erkek hasta bildirdik. Hastanın postoperatif 9 aylık takibinde rekürrens saptanmadı.

Anahtar kelimeler: Burun tıkanıklığı, nazal polip, paranazal sinüs hastalığı, nazal cerrahi işlem

Herein, we reported a patient with sphenochoanal polyp and discussed the diagnosis and treatment of disease.

\section{CASE}

A 30 years-old male patient referred to our outpatient clinic with the complaint of ongoing headache for two years and intermittent nasal congestion. The patient did not have a diagnosis of allergy. There was no pathology at anterior rhinoscopy. Polypoid mass was observed during the endoscopic examination of the nasal cavity. First it was thought as antrochoanal polyp. Mucosa of nasal cavity and turbinates was decongested with cotton (impregnated with $1 \%$ lidocaine with epinephrine $1: 100,000$ ) for detailed endoscopic examination. The pedicle of the 
polyp was traced with the tip of aspirator. The scope was advanced posteriorly through the nasal cavity, no pathology was observed in the middle meatus. To examine the sphenoethmoid recess, the scope was passed medial to the middle turbinate. Then the polyp was observed as originating from sphenoid sinus, causing the expansion of the anterior wall of sinus and extending to nasopharynx. In paranasal sinus tomography, a solitary mass with low density originating from right sphenoid sinus and expanding the sphenoid ostium and reaching the posterior choana was reported (Figure 1). The diagnosis was sphenochoanal polyp.

The polyp was removed with fibrous and edematous portion of underlying mucosa via endoscopic transnasal approach. Sphenoidotomy was also performed. Histopathological examination of the specimen revealed as inflammatory polyp (Figure 2). He has no recurrence at postoperative 9 months of follow-up. Written informed consent was obtained from the patient for the publication of this case report and accompanying images.

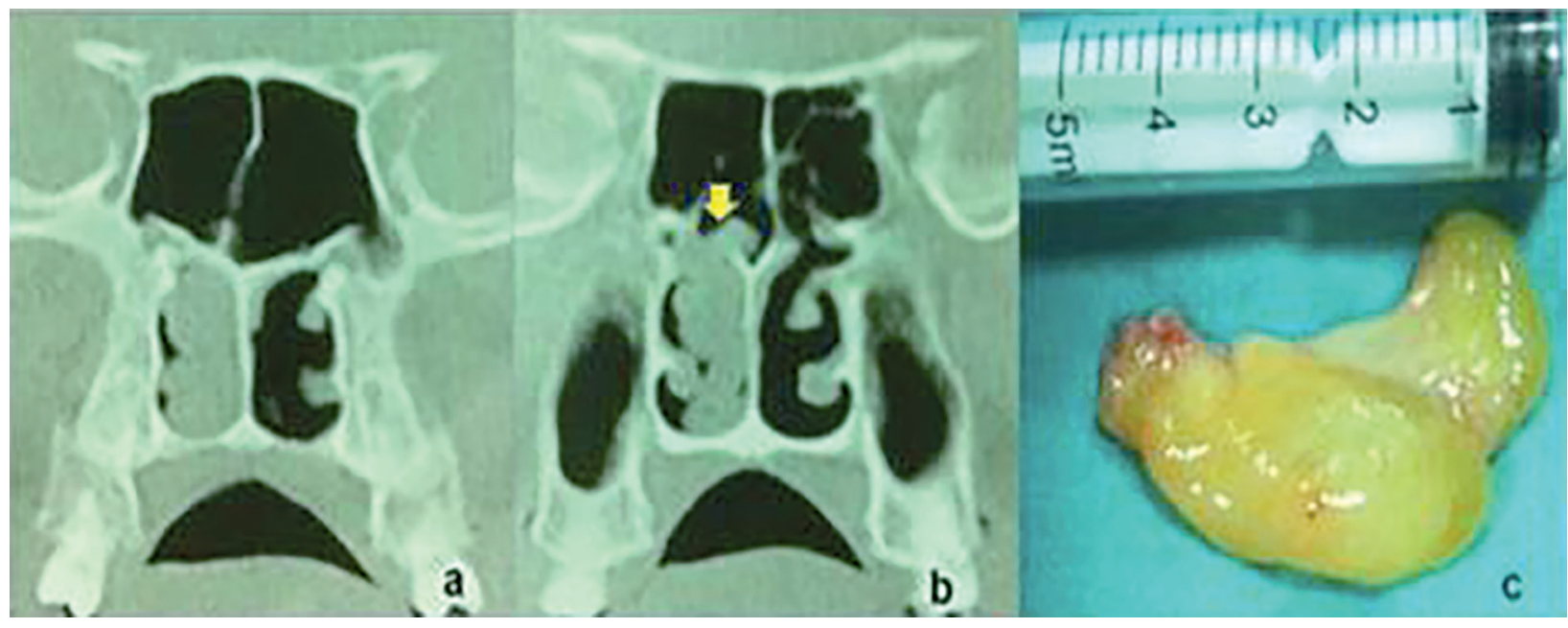

Figure 1. A solitary mass with low density which is originating from right sphenoid sinus, expanding the sphenoid os-

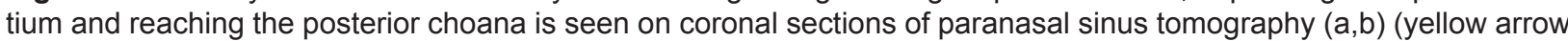
shows the sphenoid ostium). The resected specimen of sphenochoanal polyp (c).

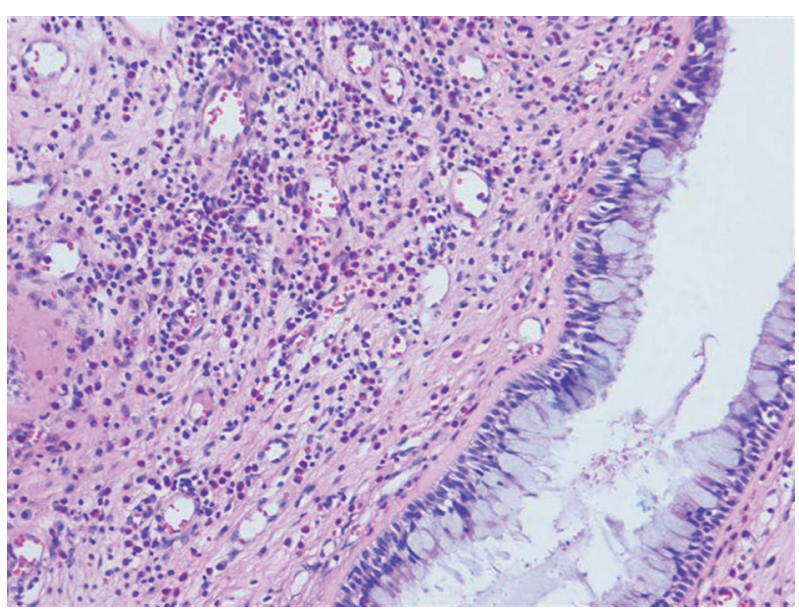

Figure 2. The histopathological section of specimen obtained from sphenochoanal polyp. The mucosa is lined by ciliated respiratory epithelium. There is an edematous and vascular stroma with dense infiltration of inflammatory cells (neutrophils, plasma cells, eosinophils and lymphocytes). (H-E x100)

\section{DISCUSSION}

Although a large part of choanal polyps originate from the maxillary sinus, very rarely they can also originate from the ethmoid cells, sphenoid sinus, inferior and middle turbinate $[3,6]$. Choanal polyps account $4-6 \%$ of the all nasal polyps with an incidence of 1-2/10000 [1]. Isolated sphenoid polyps are extremely rare. SCP was firstly reported by Zuckerkandl in 1892 . More than $50 \%$ of SCPs are observed in children $[7,10]$. The etiology of SCP is not clearly defined, but chronic obstruction of the sinus ostia, as well intramural cysts originating from sinuses are blamed as causative factors [11]. In addition, episodes of the recurrent sinusitis may lead to obstruction and rupture of the mucous glands, consequently cause expansion of the mucoceles which predispose to formation of the SCP [11]. SCPs are more common in children with cystic fibrosis and immotile cilia syndrome [12]. It is widely accepted that SCP originates from a submucosal 
cyst secondary to thrombosis of lymphatic vessels caused by inflammation that is related to infection or allergy $[8,13]$. The role of allergy or immunological deficiency is controversial. Ileri et al.[7] believe that the polyps grow under the influence of inflammatory and allergic conditions but Crampete et al.[8] do not agree. In the reported case the patient did not have a diagnosis of allergy.

Patients with SCP often apply to clinics with the complaint of headache, nasal congestion $(70 \%)$, single or double sided runny nose $(52 \%)$ and snoring. Foreign body sensation at nasopharynx due to mass affect, difficulty in swallowing, hearing loss associated with Eustachian tube dysfunction may be mentioned as the other symptoms [8]. For the diagnosis of SCP a detailed transnasal endoscopy, computerized tomography (in axial and coronal plane) and magnetic resonance imaging are useful. On tomography, SCP seems low density solitary mass extending from sphenoethmoidal recess to choana. MRI helps in the differential diagnoses of neoplastic process such as malignant melanoma, angiofibroma and inverted papilloma [8]. The combined use of imaging techniques and diagnostic nasal endoscopy is suggested for accurate diagnosis of isolated sphenoid sinus lesions and minimally invasive techniques to be tailored to the patient's disease [10].

Endoscopically, SCP usually presents between nasal septum and middle turbinate, as opposed to the antrochoanal polyp which seems in the middle meatus and passes between the middle turbinate and lateral nasal wall $[3,8]$. SCP should be kept in mind in the differential diagnosis of antrochoanal polyps. Identification of the origin of the polyp endoscopically is essential for the surgical procedure. Transnasal endoscopic excision of the polyps is the treatment of choice. Since recurrence is an important problem after surgery, patients should be followed regularly. Risk of recurrence can be minimized by expanding the sphenoid ostium (sphenoidectomy) and complete removal of the cystic component and polyp with underlying edematous mucosa [14,15]. In the reported case, the polyp and underlying fibrous and edematous mucosa was excised with endoscopic transnasal approach in conjunction with a wide sphenoidotomy. The removal of posterior-inferior part of middle turbinate was suggested as optional to improve the area exposed during excision of SCP. However, it is usually not preferred to preserve the nasal physiology and anatomy $[7,13]$. Therefore, we did not perform it in the reported case.
Sphenochoanal polyps is a rare benign mass and can cause unilateral nasal congestion, nasal discharge, headache and snoring. It should be kept in mind in the differential diagnosis of other choanal polyps and intranasal masses. Detailed endoscopic examination and imaging techniques are needed for proper evaluation of the cases. Transnasal endoscopic resection can be a quite safe method of treatment. However recurrence may be the problem, which can be prevented by complete removal of the cystic component of polyp and underlying edematous tissue. Regular follow-up is essential.

\section{REFERENCES}

1. Ozbay M, Yorgancilar E, Kinis V, et al. A rare cause of nasal obstruction: Sphenochoanal polyp. J Clin Exp Invest 2012;3:435-437.

2. Peker A, Peker E, Erden I. Discrimination of benign and malign sinonasal masses with diffusion-weighted MR imaging. Dicle Med J 2014;41:522-525.

3. Weissman JL, Tabor EK, Curtin HD. Sphenochoanal polyps: evaluation with CT and MR imaging. Radiology 1991;178:145-148.

4. Mills CP. Secretory cysts of the maxillary antrum and their relation to the development of antrochoanal polyp. J Laryngol Otol 1959;73:324-34.

5. Gordts F, Clement PA. Unusual choanal polyps. Acta Otorhinolaryngol Belg 1997;51:177-180.

6. Akduman D, Karaman M, Aydin E, et al. Coincidence of conchachoanal polyp and complete mulberry hypertrophy of inferior concha. Laryngoscope 2009;119:762-764.

7. Ileri F, Köybaşioĝlu A, Uslu S. Clinical presentation of a sphenochoanal polyp. Eur Arch Otorhinolaryngol 1998;255:138-139.

8. Crampette L, Mondain M, Rombaux P. Sphenochoanal polyp in children. Diagnosis and treatment. Rhinology 1995;33:43-5.

9. Spraggs PD. Radiological diagnosis of spheno-choanal polyp. J Laryngol Otol 1993;107:159-160

10. Sethi DS. Isolated sphenoid lesions: diagnosis and management. Otolaryngol Head Neck Surg. 1999;120:730-736.

11. Berg O, Carenfelt C, Silfverswärd C, Sobin A. Origin of the choanal polyp. Arch Otolaryngol Head Neck Surg 1988;114:1270-1271.

12. Myers EN, Cunningham MJ. Modified Caldwell-Luc approach for the treatment of antral choanal polyps. Laryngoscope 1986;96:911-913.

13. Lessa MM, Voegels RL, Pádua F, et al. Sphenochoanal polyp: diagnose and treatment. Rhinology 2002 ;40:215-216.

14. Ozcan M, Ozlugedik S, Ikinciogullari A. Simultaneous antrochoanal and sphenochoanal polyps: a rare clinical entity. J Laryngol Otol 2005;119:152-154.

15. Tysome JR, Saleh HA. Sphenochoanal polyp presenting with concomitant nasal polyps. Ear Nose Throat J 2007;86:50-52. 